\title{
Undiscovered Potential in the Basement: Exploring in Sumatra for oil and gas in naturally fractured and weathered basement reservoirs
}

\author{
Tako Koning ${ }^{1 \#}$, Nick Cameron ${ }^{2}$ and John Clure $^{3}$ \\ ${ }^{1}$ Consultant, Calgary, Canada \\ ${ }^{2}$ Geolnsight Ltd., UK \\ ${ }^{3}$ Consultant, UK \\ \#Corresponding author: tako.koning@gmail.com
}

\section{INTRODUCTION}

This paper provides and up-to-date and in-depth review of the status of exploration for oil and gas in naturally fractured and weathered basement throughout Sumatra. Also reviewed is the status of oil and gas production from Sumatra's basement fields. In this paper's section on Economic Impact, we emphasize the major positive contribution to Indonesia's economy resulting from gas produced from basement reservoirs in the South Sumatra Basin.

This paper was first
published in GEOExPro
magazine, Vol. 18, No.
1, 2021, both in print
and electronically
(Koning et al., 2021) and
is republished with
permission from
GEOExPro. For Berita
Sedimentologi, we have
made various changes
to the existing text and
figures by including
further results from our
ongoing in-depth
research into the
geology of basement oil
and gas plays in
Sumatra.

\footnotetext{
Copyright (C2021. FOSI. All rights reserved.

Manuscript received August $4^{\text {th }}, 2021$, revised manuscript received August $9^{\text {th }}$, 2021, final acceptance August 10 $0^{\text {th }}, 2021$.
}

DOI: $10.51835 /$ bsed.2021.47.2.320 
Sumatra, Indonesia is the sixth largest island in the world covering an area of $445,000 \mathrm{sq} \mathrm{km}$. The first significant oil discovery in Asia was found in 1885 at Telaga Said in North Sumatra. Telaga Said was the foundation asset of Royal Dutch Shell. Sumatra has been a major producer of hydrocarbons and has current total discovered resources of almost 28 billion barrels of oil equivalent $(\mathrm{BBOE})$ based on the North Sumatra Basin with $6 \mathrm{BBOE}$, Central Sumatra Basin with 15 BBOE (Darwis et al., 2007 and Meckel, 2013, and this paper) and our estimate for the South Sumatra Basin with 6.7 BBOE. Although Sumatra is now viewed by many as a mature hydrocarbon

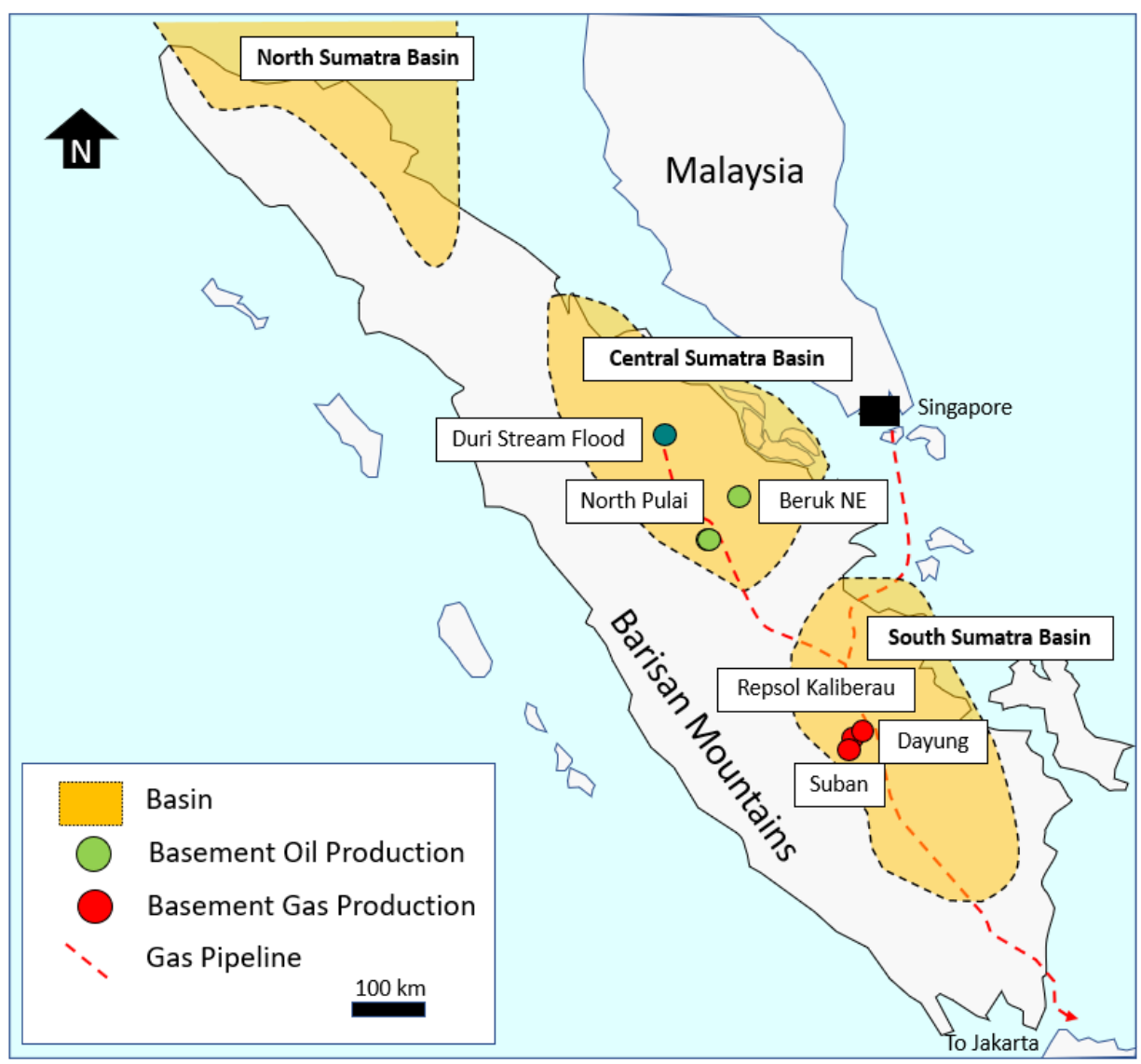

Figure 1. Location of the discussed basement oil and gas discoveries. More detail on basement hydrocarbon occurrences in the South Sumatra Basin is provided in Figure 2. province, a major gas discovery by Repsol in February 2019 in fractured basement rocks highlights that there is still significant potential for further discoveries of oil and gas in Sumatra.

Repsol's discovery well was the Kaliberau Dalam (KBD)-2X well, drilled on the Sakakemang Block in the South Sumatra Basin and encountered at least $2 \mathrm{TCF}$ of recoverable gas and condensate. The well targeted the basement reservoirs that are highly gas productive in the nearby Corridor Block operated by ConocoPhillips. This was the largest hydrocarbon discovery in Indonesia in 18 years since the ExxonMobil Cepu oil discovery in 2001 in Central Java

(Wood Mackenzie, 2019). The KBD-2X well was reported to have flowed gas at $45 \mathrm{MMCF} / \mathrm{d}$. Repsol as operator has a $45 \%$ interest in the discovery along with partners

Petronas with $45 \%$ and Mitsui with $10 \%$.

During the many decades of exploration in Sumatra, little attention was placed on exploring for oil or gas in basement. This 
lack of interest in basement is due to a general perception of the industry worldwide that basement is typically "tight" and did not warrant investigation. Most discoveries of oil and gas in basement were made "by accident" rather than by deliberately exploring the basement. Giant oil discoveries in naturally fractured and weathered basement in Venezuela in 1953, Libya in 1965 and Vietnam in 1975 (Koning, 2020) encouraged more exploration worldwide in basement. However, exploration in basement in Sumatra remained minimal until 1991 when the first major basement gas discovery was made in the South Sumatra Basin.

\section{SOUTH SUMATRA BASIN}

Oil was first discovered in the South Sumatra Basin in 1896 in the Kampong Minyak field (van Bemmelen, 1949). In the Palembang sub-basin of the South Sumatra Basin, oil and gas in basement was discovered in 1913 in the Kluang Field (Martin, 1952). The Sei Teras pool (Tiwar and Taruno, 1979), which was discovered in 1977, flowed a minor amount of oil and gas from basement. In 1988, Pertamina discovered oil and gas in basement in the Kuang area in the ASD- 1 well which flowed oil at 1,824 BOPD from granodiorite (Sardjito et al., 1991). Subsequent wells were less productive

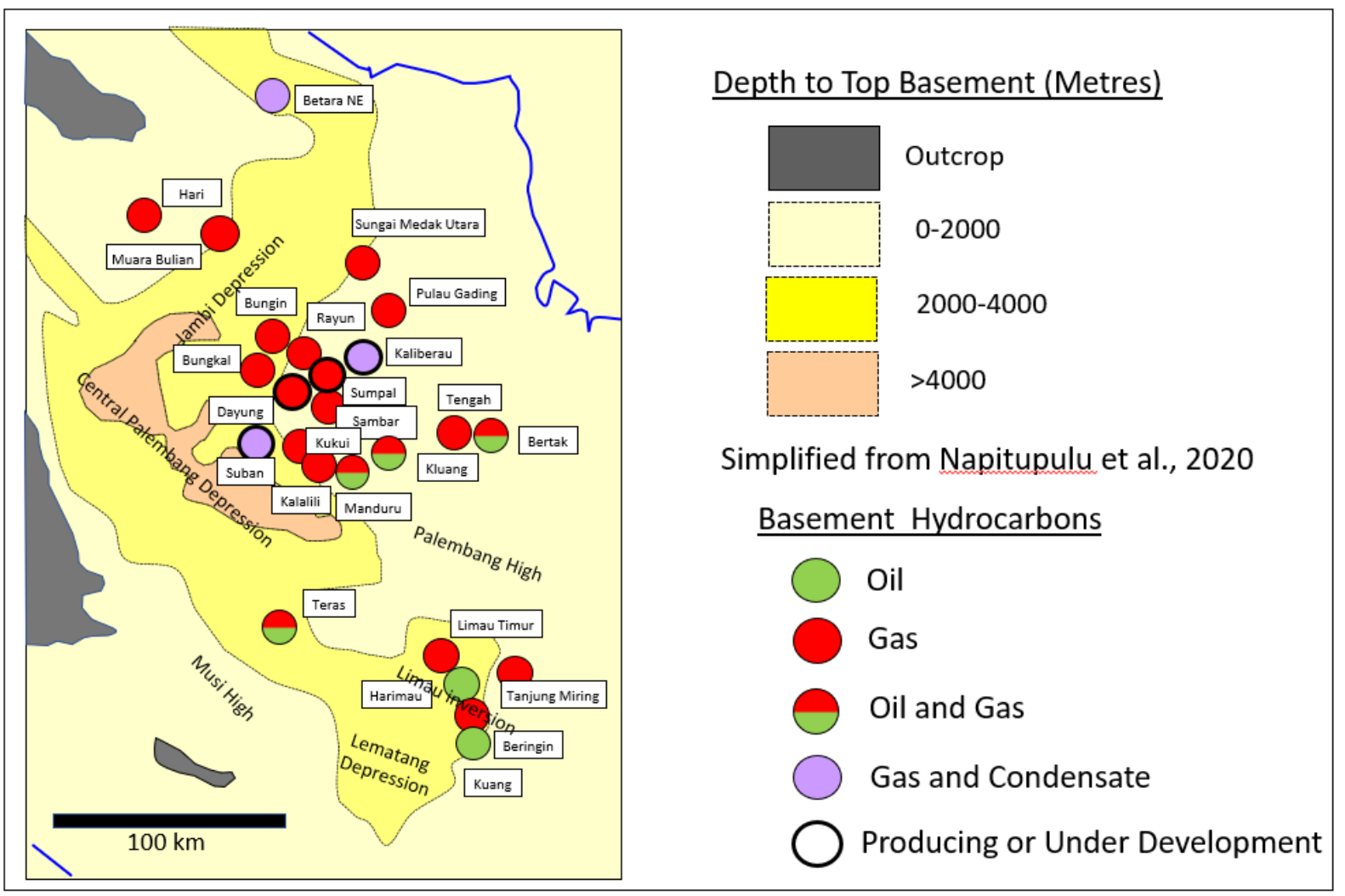

Figure 2. South Sumatra Basin basement hydrocarbon occurrences. Their pattern is suggestive of a dominant hydrocarbon expulsion direction up-dip eastwards out of the source bearing depocenters. Clearly demonstrated by Napitupulu et al, (2020) is the ideal location of the Suban region to trap large volumes of migrating hydrocarbons owing to the proximal location of the depocenters and, more critically, the exceptional vertical relief of the structures. 
with oil flow rates between $6-88$ BOPD from basement.

This abruptly changed in 1991 with the discovery by Gulf Indonesia (legacy Asamera Oil) of a major gas field in basement at Dayung-1. This well in the Gulf-operated Corridor Block was rapidly followed up by seven more major basement gas discoveries that culminated in 1998 with the finding of the Suban Field with 5-7 TCF of gas and condensate reserves. The gas reserves of these eight discoveries were estimated at 15 TCF (Zeliff, 2001). Repsol's discovery in 2019, now called the Kaliberau Field, is the first major discovery of gas in basement reservoirs in the last two decades in the South Sumatra Basin.

A more recent discovery of gas in a basement 'buried hill' was the NEB-X-1 exploration well drilled by China National Petroleum Corporation (CNPC) in 2017 on the Jabung Block which tested gas at $2.1 \mathrm{MMCF} / \mathrm{d}$ and condensate at 240 BCPD (Ming et al., 2019). Though our records remain incomplete, Figure 2 demonstrates that basement hydrocarbon shows are surprisingly widespread throughout the South Sumatra Basin.

The basement reservoirs comprise Jurassic granites and metasediments whose ages range from Carboniferous to Jurassic (Barber and Crow, 2005). The complexity of the play is illustrated by the lithologies of the Dayung Gas Field where the host rock which includes Permian marbles is invaded by hydrothermally altered granites (Darmadi et al., 2013 and Sagita et al., 2008). As is apparent from Figure 3a, the gas discoveries lie at the intersection of two trends. These are: 1) NE-SW running, rift related highs formed during the Oligocene and 2) late Miocene and younger, WNW-ESE aligned, compressional features formed above Mesozoic lines of weakness (Figure 3b). Maximum fracturing is likely in such settings. The rift created

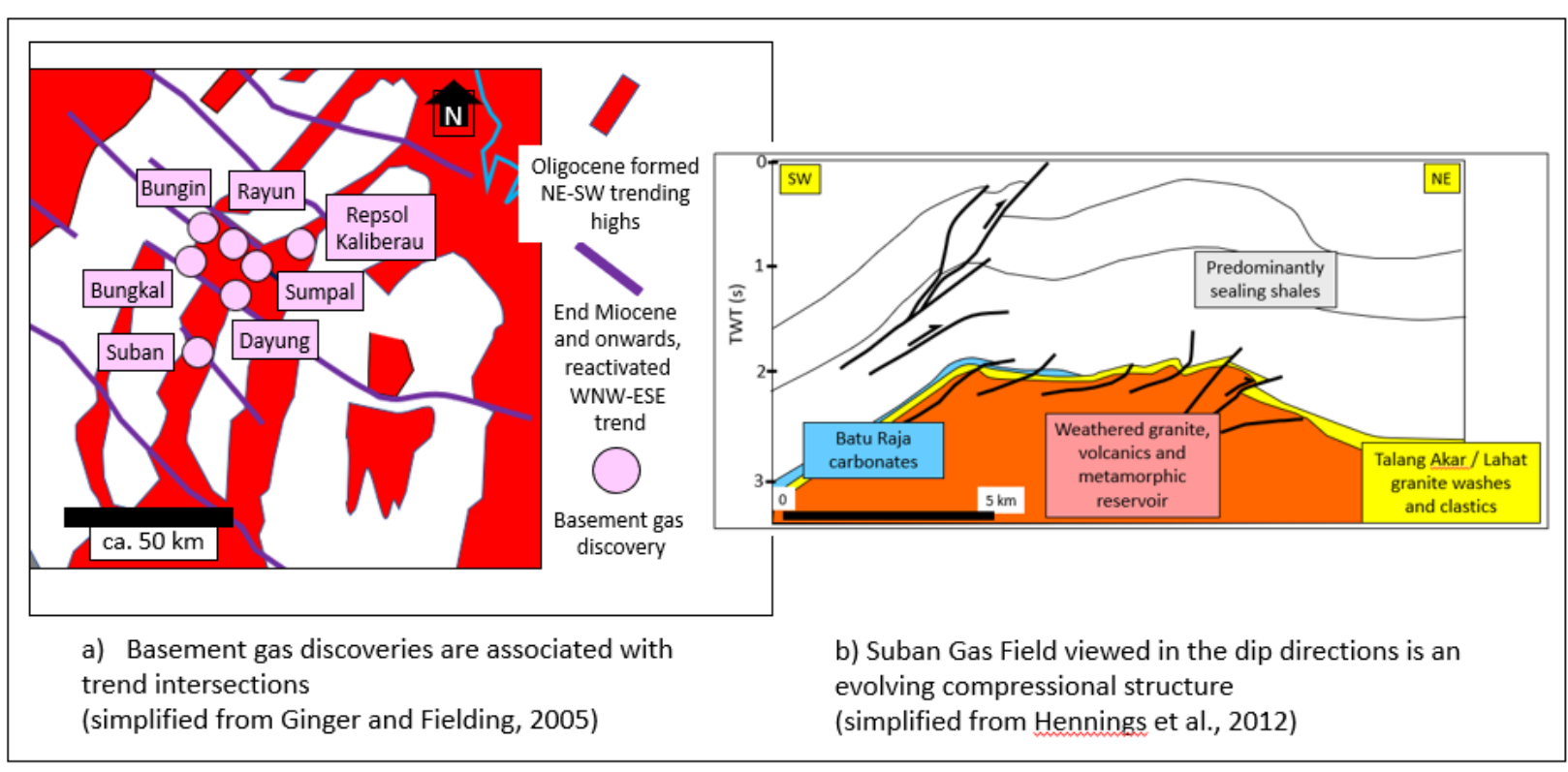

Figure 3. Structural influences on the South Sumatra Basin basement gas discoveries. 


\begin{tabular}{|l|c|}
\hline Formation & Oil (Bboe) \\
\hline Late Miocene Muara Enim & 0.2 \\
Middle Miocene Air Benakat & 0.6 \\
Early Miocene - Middle Miocene Gumai & 0.1 \\
Early Miocene Batu Raja & 1.0 \\
Early Miocene - Late Oligocene Talang Akar & 2.0 \\
Basement gas found including Kaliberau & $2.8 \quad$ (17 TCF) \\
\hline Estimated yet-to-find basement gas & $0.8 \quad$ (5 TCF) \\
\hline Total oil and gas & 7.5 \\
\hline
\end{tabular}

Table 1. South Sumatra Basin: estimated ultimate oil and gas production.

highs which survived as "buried hills" in the Miocene before being covered by Gumai sealing shales. They were subject to deep weathering and are the origin of Talangakar reservoirs sands and granite washes. The gas was sourced from the Talangakar and Lahat succession (Clure, 2005).

Wells with sustainable flow rates more than $200 \mathrm{MMCF} / \mathrm{d}$ have been reported such as in the Sumpal Field. Most of the Corridor Block fields have clearly defined gas-water contacts and the basement traps are filled to spill-point. In the Suban Field, the gas column rests on water and has a height of $1,450 \mathrm{~m}$. In some Suban wells, granitic basement is deeply weathered with up to $155 \mathrm{~m}$ of weathering (Hennings et al., 2012) thereby creating a thick section of reservoir rock at the top of basement. The excellent gas deliverability of the basement reservoir is illustrated by Suban-11 which had an Absolute Open Flow (AOF) rate of $1 \mathrm{BCF} / \mathrm{d}$ and deliverability rate of $150 \mathrm{MMCF} / \mathrm{d}$. Well trajectories are critically important since wells must be drilled perpendicular into the dominant fracture orientations to maximize gas production (Hennings et al., 2012). The highest flow rates are associated with active fracturing and tracking their location is a critical factor in optimizing the field's development (Schultz et al., 2014 and Figure 2b).

Data on the composition of the gases in basement in the Corridor Block fields are limited. Abdurrahman et al. (2015) reported carbon dioxide $\left(\mathrm{CO}_{2}\right)$ ranges from $32-90 \%$. Suban is distinctive in having a much lower $\mathrm{CO}_{2}$ content of only 5.5\% (Gulf Indonesia, 1999). This field supplies more than $70 \%$ of the gas production from the Corridor Block (Mohede et al., 2014). The $\mathrm{CO}_{2}$ must be removed prior to the gas being exported by pipeline.

Table 1 presents our estimate of the basin's ultimate oil and gas production. It was prepared from various sources including Bishop (2001) and Darwis et al. (2007).

A 'super basin' is defined by the American Association of Petroleum Geologists (AAPG) as a basin that has produced at least 5 billion barrels of oil equivalent (BBOE) and contains at least another 5 BBOE future production (Fryklund and Stark, 2020). Based on our analysis, the South Sumatra Basin is on the verge of becoming a super basin due to the 
continued impact of the basement gas play. We consider it reasonable to assume that at least a further $5 \mathrm{TCF}$ of basement gas could be discovered given pattern of expulsion suggested by Figure 2. Our estimate of 5 TCF entails finding, for example, no more than one more Suban or five Dayung-sized fields.

\section{CENTRAL SUMATRA BASIN}

The Central Sumatra Basin has produced prodigious volumes of oil since the Duri oil field commenced production in 1944. This basin is classified as a super basin. Except for the small North Pulai and Beruk Northeast basement oil pools, all the production in this basin has been from Oligocene and Miocene clastics. The giant Duri heavy oil field was discovered in 1941 and has produced 2 billion barrels of oil. The giant Minas oil field, discovered in 1944, is the largest oil field in S.E. Asia, has 9 billion barrels original oil-in-place and has produced to date approximately 5 billion barrels of oil.

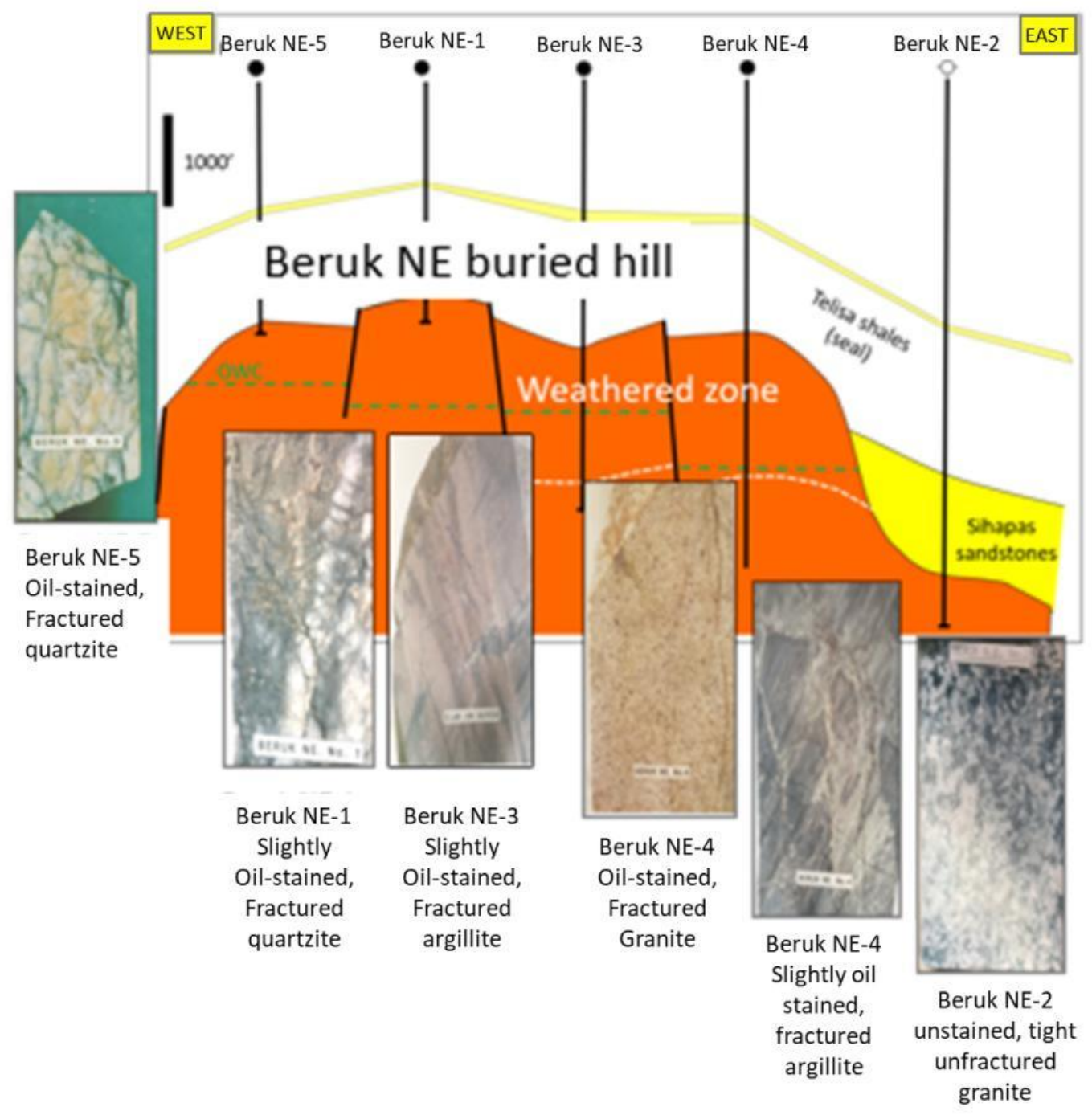

Figure 4. Beruk Northeast oil field cross-section and basement cores. All the cores were taken at the bottom hole, and each are about $15 \mathrm{~cm}$ long (modified after Koning and Darmono, 1984). 
The first discovery of oil in basement in the Central Sumatra Basin was the small North Pulai field found in 1951 within a faulted anticline located on the Lirik Trend (Clure, 2005). The basement reservoir consists of PreTertiary quartzites which is overlain by late Oligocene Lakat sandstones. A $49.5 \mathrm{~m}$ oil column occurs in basement and the overlying Lakat sandstones have a $74.0 \mathrm{~m}$ oil column. Net pay in basement was $4.3 \mathrm{~m}$ and in the Lakat was $7.9 \mathrm{~m}$ (Courteney et al., 1991). Cumulative oil production up to 1990 from North Pulai was 37.5 MMBO with presumably half (19 MMBO) from basement and the other half from the Lakat. Pertamina is the operator of the North Pulai field.

In 2011, Pertamina drilled exploration well Nira-1 located geologically ontrend with North Pulai. Nira-1 penetrated $350 \mathrm{~m}$ of metamorphic basement and discovered noncommercial biodegraded heavy oil in basement and was abandoned (Wahyudin et al., 2015). From the same trend, Setiawan et al. (2013) described the 1982 basement discovery in the S-2 well. This well produced oil, but only limited information is available. The records point to a marginal oil discovery, perhaps a single well oil pool. We suspect the primary reason for the lack of success in this well is the presence basement rocks consisting of greywackes, argillites, phyllites and volcanics, which are rock types that tend have only tight fracture systems and are not conducive to deep weathering.

More significant was the discovery of oil in basement in the Beruk Northeast oil pool. BNE-1 was drilled by Caltex (Chevron \& Texaco) in 1976 and tested oil at $1,600 \mathrm{Bpd}$ from fractured quartzite (Koning and Darmono, 1984 and Figure 4). Beruk Northeast was placed on production in 1981 and experienced rapid influx of formation water. Cumulative oil production has been only 2.6 MMBO. The disappointing results are due to poorly defined thin oil columns in basement and the high variability of the basement lithologies.

Noteworthy also is that more recently Caltex drilled a few wells into the basement high beneath the Minas oil field. We have learned through informal communications that those wells were water-bearing. The failure of these wells is attributed to the absence of a sealing shale

\begin{tabular}{|l|l|l|c|}
\hline Beruk NE well & Lithology & Age & Oil flow rate (Bpd) \\
\hline BNE-1 & Quartzite & Permian & 1600 \\
BNE-2 & Granite & Jurassic & Tight \\
BNE-3 & Argillite & Cretaceous & 200 \\
BNE-4 & Granite & Triassic & 200 \\
BNE-4 & Argllite & Cretaceous & 200 \\
BNE-5 & Quartzite & Undated & 2252 (34\% water cut) \\
\hline
\end{tabular}

Table 2. Beruk Northeast pool. Basement lithologies and initial oil production flow rates. overlying basement.

Although exploration in Pre-Tertiary basement in the Central Sumatra Basin has been discouraging, the lack of success is also because there has been little serious and 
deliberate exploration for oil and gas in this basin. Most wells in the basin only "tagged" into the top of basement and may have "left behind" significant oil or gas fields. In many parts of the Central Sumatra Basin, the organically rich, world class Pematang Formation Brown Shales rest directly on basement and could feed oil or gas directly into underlying or adjacent fractured or weathered basement. The Brown Shale would serve as both a source and seal.

\section{NORTH SUMATRA BASIN}

The geology of the North Sumatra Basin has been published on by many researchers including Cameron et al. (1980). The North Sumatra Basin is the least oil-productive of Sumatra's three basins. However, it does contain the super-giant Arun gas field with reserves of 15 TCF gas (Meckel, 2013). No oil or gas has been reported from definite basement in this basin, although in the literature hydrocarbons within the Eocene-aged, Tampur carbonates are often referred to as basement occurrences (for example Wahyudin et al., 2015). Our opinion is that this basin has the geological ingredients required to contain significant, true basement hosted, oil and gas deposits. Especially favorable is the deep succession below the Arun region with its narrow horsts and deep Bampo source grabens (Meckel, 2013).

\section{WHY JUST THE SOUTH SUMATRA BASIN?}

It remains unclear why only the South Sumatra Basin has yielded significant

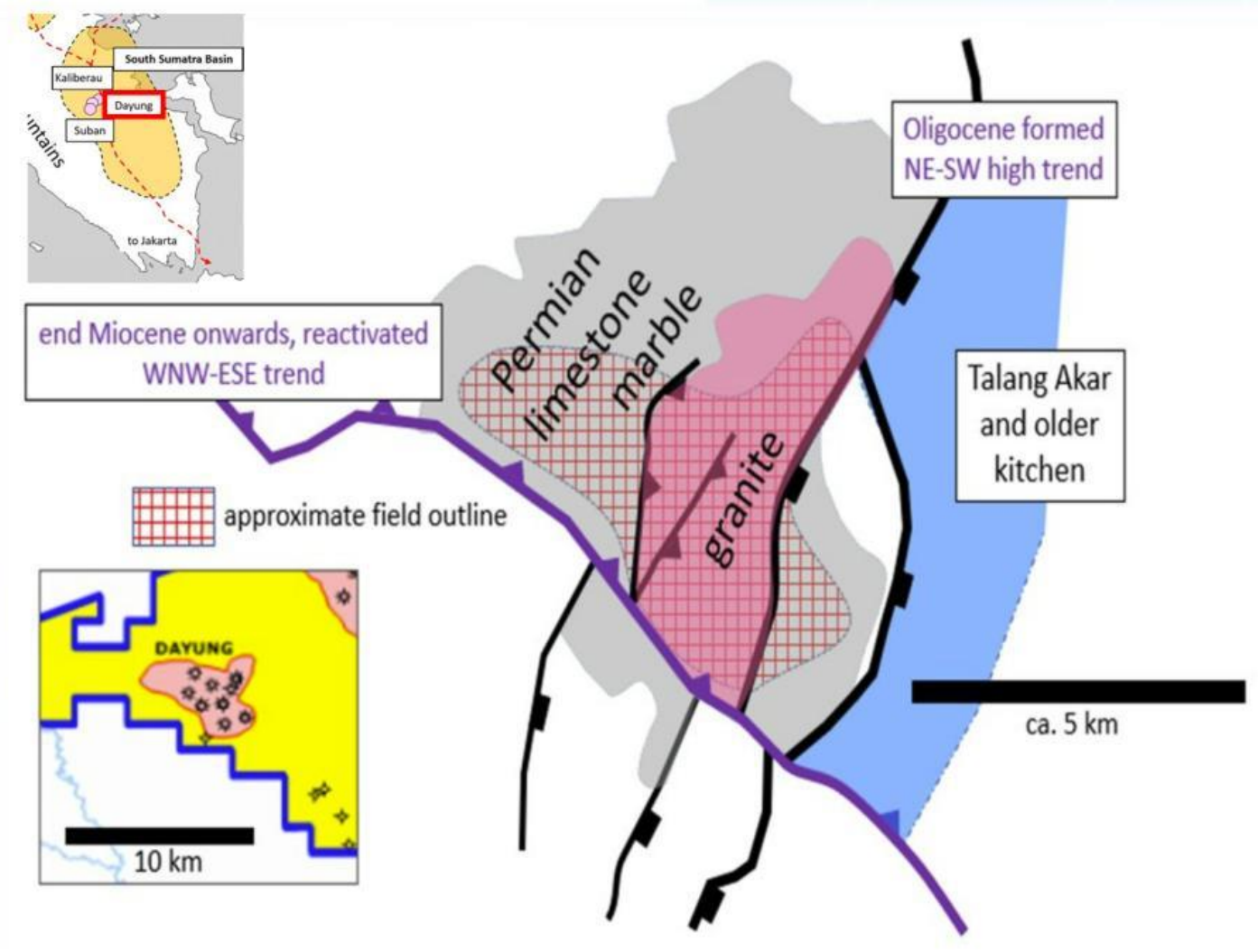

Figure 5. Dayung Field outline and top basement surface. Modified after Sagita et al. (2008) and Permana et al. (2016). 
basement finds when the geology of the Central and North Sumatra basins with their rich source succession is optimal for their presence given the island's long history of basement disruptive tectonics. One reason may be a lack of deeper basement intersections as top basement shows are not uncommon as is evident from Figure 2. For the South Sumatra Basin, two other factors are in play. The first is that the cross-cutting fault sets are prominently developed at the gas discovery locations. The second and perhaps critical one is, following the publication by Sagita et al. (2008) of Tertiary radiometric ages from the hydrothermally altered granites at Dayung, is that rather than fractured, Pre-Tertiary basement, it is altered granites and their hydrothermal aureoles that are supplying prolific pay zones. Furthermore, it could be that intrusions are focused on the fault set intersects resulting in the further enhancement of porosities. Such a possibility is evident in the figures provided by Sagita et al. (2008) and combined to form Figure 5.

It is these granites and their aureoles that we consider will yield the bulk of the additional 5 TCF yet-to-find gas for this basin. Given the induced, hydrothermal nature of the porosity, conventional structural traps may not be required, provided there is access to migrant hydrocarbons and top seal exists. Smaller finds may now be economic since the infrastructure for their development already exists. Wood Mackenzie (Anon, 2019) regard the economic cut off as $300 \mathrm{BCF}$ for satellites to producing fields. However, in the past year the price of gas in Asia has increased dramatically mainly due to significantly increased imports of LNG (Liquified Natural Gas) by China. Accordingly, gas fields with considerably less than $300 \mathrm{BCF}$ may now be economically feasible. Finding such small volume bodies will be limited by the ability of seismic or any other exploration tool to discriminate potential pay.

With growing concerns relating to increasing atmospheric $\mathrm{CO}_{2}$, higher $\mathrm{CO}_{2}$ yielding discoveries are becoming globally less attractive. Already sequestration, always an expensive option, to Suban has been proposed as the means of disposing the $26 \% \mathrm{CO}_{2}$ present at Kaliberau (Energy Voice, 2021). A consequence is that low $\mathrm{CO}_{2}$ plays such as that associated with the Suban granite may become the preferrable target. An attraction here is the size of this discovery compared to hydrothermally related fields such as Dayung. Weathered granite plays, as they tend to form "buried hills", such as at Beruk Northeast, will be simpler to locate.

\section{ECONOMIC IMPACT}

The economic impact for Indonesia of South Sumatra's gas production is highly significant. For example, following the development of the Corridor Block's basement gas fields, in 2001 Singapore signed a 20-year agreement with Indonesia to buy 2.3 TCF gas from South Sumatra for $\$ 9$ billion. The agreement called for Indonesia to export $350 \mathrm{MMCF} / \mathrm{d}$ through a $500 \mathrm{~km}$ pipeline constructed between the two countries. Total gas production from South Sumatra was assessed by Abdurrahman et al. (2015) to be $1.9 \mathrm{BCF} / \mathrm{d}$, almost $70 \%$ of which 
was supplied by ConocoPhillips. Deliveries are to the Duri Steam Flood, Singapore, and Java. Further exploration for gas in the South Sumatra Basin is strongly supported by the Indonesian government which is aiming to double the nation's gas production in the next 10 years and become one of the top global gas exporters (Harsono, 2020).

However, in the short-term Indonesia is faced with a looming natural gas deficit estimated to happen in 2025 when consumption is greater than domestic supply. To partially mitigate this deficit, in 2019 Pertamina signed a long-term contract with Anadarko Petroleum to buy 1 million tonnes per year of LNG for 20 years from the yetto-be-constructed Mozambique LNG terminal (Tan, 2019). On February 10, 2020, Indonesia's Downstream Oil and Gas Regulatory Agency (BPH Migas) announced that Indonesia would stop gas exports to Singapore in 2023 to meet the ever-increasing domestic demand for gas. The announcement said that this would create added value for Indonesia's natural gas by using gas to replace oil for power generation and reduce its trade deficit as the use of gas would lessen the consumption of expensive imported oil. The gas is also much needed by industries in Indonesia such as petrochemicals, fertilizers, ceramics, and steel. The government strongly encouraged Repsol to fast track the development of Kaliberau so it can be producing gas by 2024 - 2025 (Evans, 2020). This has resulted in positive action with Repsol having now re-entered KBD-2XST1 and completed the well as a production well. The first infill well has also been drilled and completed as a gas producer (Energy Voice, 2021).

Accordingly, it is our view that there is potential for more gas discoveries in Sumatra such as the Kaliberau basement gas discovery which will be much welcomed by Indonesia's government and economy.

\section{ACKNOWLEDGEMENT}

Mike Crow provided guidance on the nature and origin of the igneous bodies in the Suban and Dayung fields. We also wish to acknowledge MapStand for the use of their maps of Sumatra.

\section{REFERENCES}

Abdurrahman, M., Bae, W., and Kim, S., 2015. $\mathrm{CO}_{2}$ sources and future EOR prospects in Sumatra island-Indonesia. Advances in Civil Environmental and Materials Research, Incheon, Korea, August 25-26, 2015, p. 7.

Anon, 2019. Repsol makes gas discovery at Sakakemang, Indonesia. Oil and Gas Journal, 11 March 2019.

Barber, A.J. and Crow, M.J., 2005. Structure and structural history. In: Barber, A.J., Crow, M.J., and Milsom, J.S. (Eds), Sumatra Geology, Resources and Tectonic Evolution. Geological Society Memoir 31, Chapter 13, p. 175233.

Bishop, M.G., 2001. South Sumatra Basin Province, Indonesia: The Lahat/Talang Akar - Cenozoic total petroleum system. United States Geological Survey (USGS) Open-File Report, 99-50-S. 
Cameron, N. R., Clarke, M. C. G., Aldiss D.T., Aspden J.A., and Djunuddin, A., 1980. The geological evolution of the North Sumatra Basin. Proceedings of the $9^{\text {th }}$ Indonesian Petroleum Association, p. 149-197.

Clure, J., 2005. Fuel resources: oil and gas. In: Barber, A.J., Crow, M.J., and Milsom, J.S. (Eds), Sumatra Geology, Resources and Tectonic Evolution. Geological Society Memoir No. 31, Chapter 10, p. 131 - 141.

Courteney, S., Cockcroft, P., Lorentz, R.A., Miller R., Ott, H.L. Prijosoesilo, P., Suhendan, A. R., and Wight, A.W. R., 1991. Indonesia - Oil and Gas Fields Atlas, Volume II: Central Sumatra. IPA Professional Division.

Darmadi, Y., Harahap, A., Achdiat, R., Ginanjar, M., and Hughes, J., 2013. Reservoir characterization of fractured basement using seismic attributes, Dayung Field case study, South Sumatra Basin. Indonesian Petroleum Association, paper IPA13-G-155.

Darwis, A., Saputra, S.E., and Drianto, S., 2007. Exploring in mature basins in Sumatra (Sumatera) Island, Indonesia: a historical review to challenge new ideas. AAPG Search \& Discovery Article \#10139.

Energy Voice, 2021. Repsol finishes FEED for giant Indonesian gas discovery, 26 July 2021. Available online at:

https://www.energyvoice.com/oilandg as/asia/339310/repsol-finishes-feedfor-giant-indonesian-gas-discovery
Evans, D. 2020. Indonesia plays hardball with Repsol over gas pricing. Energy Voice, November 12, 2020.

Fryklund, B. and Stark, P., 2020. Super basins - new paradigm for oil and gas supply. Bulletin American Association Petroleum Geologists, 104, 12, p 2507-2519.

Ginger, D. and Fielding, K., 2005. The Petroleum Systems and Future Potential of the South Sumatra Basin. Indonesian Petroleum Association, paper IPA05-G-039.

Gulf Indonesia, 1999. Talisman and Pertamina confirm Suban natural gas discovery. Press release, January 7, 1999.

Harsono, N., 2020. Indonesia aims to double gas production by 2030 with major projects in pipeline. The Jakarta Post March 9, 2020. Available online at:

https://www.thejakartapost.com/new s/2020/03/09/indonesia-aims-todouble-gas-production-by-2030-withmajor-projects-in-pipeline.html

Hennings, P., Allwardt, P., Paul, P., Zahm, C., Reid, R. Jr., Alley, H., Kirschner, R., Lee, B., and Hough, E., 2012. Relationship between fractures, fault zones, stress, and reservoir productivity in the Suban gas field. Sumatra, Indonesia. Bulletin American Association Petroleum Geologists, 96, 4, p. 763-772.

Koning, T., Cameron, N.R. and Clure, J., 2021. Undiscovered potential in the basement. Exploring in Sumatra for oil and gas in naturally fractured and weathered basement reservoirs. 
GEOExPro, Vol. 18, No. 1, March 2021, p. 26-29. Available online at:

https://www.geoexpro.com/articles/2 021/03/undiscovered-hydrocarbonpotential-in-sumatra

Koning, T., 2020. Exploring in Asia for oil and gas in naturally fractured and weathered basement reservoirs. Geoconvention virtual event, 21-23 September 2020. Available online at:

https://geoconvention.com/wpcontent/uploads/abstracts/2020/579 81-exploring-in-asia-for-oil-and-gasin-naturally-fra.pdf

Koning, T. and Darmono, F.X., 1984. The geology of the Beruk Northeast Field Central Sumatra: oil production from Pre-Tertiary basement rocks. Proceedings of the 14th Indonesian Petroleum Association, p. 117-137.

Martin, R., 1952. The development and oil-bearing of the Lower Telisa Formation in South Sumatra. Unpublished report. N.I.A.M., July 29, 1951, Pladju, South Sumatra.

Meckel, L.D. III, 2013. Exploring a 19 th century basin in the 21 st Century: seeing the North Sumatra Basin with new eyes. AAPG Search and Discovery Article \#10464.

Ming L., Kong, X., Hong, G., Hu, G., Zhu, H., and Ma, Y., 2019. New play discoveries in the South Sumatra Basin, Indonesia - exploration case study in the CNPC Jaburg Block. 10th International Conference on Petroleum Geochemistry and Exploration in the Afro-Asian Region 10-12 May 2019, Guangzhou, China.
Mohede, H., Mallick, K. M., and Tybero, G., 2014. Suban - South Sumatra giant fracture gas reservoir development and challenges. Indonesian Petroleum Association, paper IPA14-E-324.

Napitupulu, V., Jannah, M., Silaen, M., and Darman, H., 2020. Hydrocarbon columns of oil and gas fields in the South Sumatra Basin. Berita Sedimentologi, 46, p. 51-60.

Permana, B.R., Darmadi, Y., Sinaga, I. B., Kusmawan D., and Saripudin, A. 2016. The origin of oil in the Telisa Formation, Suban Baru Field, and the next exploration path. 2016 Technical Symposium, Indonesia Exploration: Where From - Where To. Indonesian Petroleum Association, paper 23-TS16.

Sagita, R., Sari, Q.C., Chalik, M., Rita, A., Waworuntu, R., and Guttormsen, J., 2008. Reservoir characterization of complex basement - Dayung. Indonesian Petroleum Association, paper IPA08-G-208.

Sardjito, E.F., Djumlati, and Hansen, S., 1991. Hydrocarbon prospect of PreTertiary basement in Kuang area, South Sumatra. Proceedings of the 20th Indonesian Petroleum Association, volume 1, p. 255-277.

Schultz, R.A., Soofi, K. A., Hennings, P.H., Tong, X., and Sandwell, D., 2014. Using InSAR to detect active deformation associated with faults in Suban field, South Sumatra Basin, Indonesia. The Leading Edge, 33, 8, p. 884-885 and 886-888. 
Setiawan, A., Rakimi, S., Siregar, R.C., Wisnu, R., Anwar, M.R., and Hendarman, 2013. Fractured basement plays in the Southern Bentu area, Central Sumatra. Indonesian Petroleum Association, paper IPA13-G047.

Tan, H.H., 2019. Indonesia to import LNG from Mozambique. Lloyd's List, Maritime Intelligence, 2009, February 20, 2019.

Tiwar, S. and Taruno J., 1979. The Tanjung (South Kalimantan) and Sei Teras Fields (South Sumatra): a case history of petroleum in Pre-Tertiary basement. Proceedings of the Committee for Coordination of Joint Prospecting for Mineral Resources in Asian Offshore Areas (CCOP). Sixteenth Session, 10 - 18/9/1979, Bandung, Indonesia, p. $238-247$. van Bemmelen, R.W., 1949. The geology of Indonesia. Martinus Nijhoff, The Hague, Netherlands.

Wahyudin, M., Samudra, A.B., Jaenudin, Bahesti, F., and Darmawan, A., 2015. New potential and underexplored fractured basement plays in the Sumatra basins. FSTH Conference, Bali, 2015 (Extended Abstract).

Wood Mackenzie, 2019. Indonesia: largest gas discovery for 18 years. GEOExPro, May 2019, p. 74.

Zeliff, G.W., 2001. A new play in a mature basin: prospecting for gas in Pre-Tertiary basement reservoirs South Sumatra, Indonesia. AAPG Search and Discovery article \#90906. 